\title{
THE DECLINE OF FEDERAL CONCURRENT EQUITY JURISDICTION
}

Long ago John Marshall declared that it would be treason to the Constitution for a federal court to refuse to decide a case within its jurisdiction and properly before it. ${ }^{1}$ If that is true, then our federal judges are doubledyed traitors indeed. They have thrown a multitude of procedural blockades in the path of the litigant seeking equitable relief in federal courts, and even when all procedural hurdles are passed, they often refuse to hear his plea.

The Eleventh Amendment denied federal courts jurisdiction in a large class of cases until the "stripping doctrine" gained final acceptance in Ex Parte Young. ${ }^{2}$ Under that doctrine federal courts could entertain actions against state officials, although the effect was the same as if the action were against the state itself. The new jurisdiction, however, was not to be easily used. Prentis v. Atlantic Coast Line, ${ }^{3}$ decided the same year as Ex Parte Young, established a doctrine which combined with Section 265 of the Judicial Code ${ }^{4}$ to introduce a serious procedural hazard in one major area of Ex Parte Young jurisdiction. The Prentis case established the rule that appeal could not be made to a federal chancellor to enjoin an administrative act until all administrative remedies had been exhausted. Section 265 provided, as it was construed, that the federal action must be brought, if ever, before an action had been brought in a state court." Thus the litigant faced the certainty of seeing his action turned out of court as being premature if he acted before exhausting all administrative processes and the danger of being too late should he wait until the agency had finished its proceedings, since a wise state administrator would commence an action in a state court immediately. The Prentis rule, of course, had no effect on actions for injunctions against enforcement of state laws outside the administrative field.

The courts were not alone in viewing procedural safeguards as necessary. Congress was alarmed at the wave of injunctions which followed the opening of the floodgates by Ex Parte Young. Fearing that state social legislation would be swamped, Congress enacted the Three Judge Court

1 "With whatever doubts, with whatever difficulties, a case may be attended, we must decide it, if it be brought before us. We have no more right to deeline the exercise of jurisdiction which is given, than to usurp that which is not given. The one or the other would be treason to the Constitution." Cohens v. Virginia, 6 Wheat. 264, 404 (1821). Followed in many cases; e.g., McClellan v. Carland, 217 U.S. 268 (1910); Willcox v. Consolidated Gas Co., 212 U.S. 19, 40 (1909); Chicot County v. Sherwood, 148 U.S. 529, 534 (1893).

2209 U.S. 123 (1908).

3211 U.S. 210 (1908).

4 The former 28 U.S.C. $\$ 379$ (1946), which read: "The writ of injunction shall not be granted by any court of the United States to stay proceedings in any court of a State, except in cases where such injunction may be authorized by any law relating to proceedings in bankruptcy." Revised in 28 U.S.C. $\$ 2283$ (Supp. 1950).

5 Supra note 4. For a very thorough discussion of the interpretation of this section, see Comment, 35 CaLIF. L. Rev. 545 (1947). 
laws, ${ }^{6}$ and later the Johnson and Tax Injunction Acts, ${ }^{7}$ to stem the tide.

The litigant who picks his way past these procedural pitfalls must face another type of blockade, one which may prove to be much stronger and more immovable. That is the blockade of judicial self-restraint, the tendency of federal courts to decline to exercise their equity powers even when all jurisdictional and procedural requirements are met.

Very early it was held that federal courts would not enjoin criminal proceedings in state courts absent special circumstances involving serious and immediate threat of irreparable injury, ${ }^{8}$ ordinarily found only when property rights were involved. ${ }^{9}$ This was in accord with ancient principles of equity, English chancellors having long before abandoned almost all their jurisdiction in criminal matters, except for the issuance of habeas corpus. ${ }^{10}$ The techmical ground for declining to exercise jurisdiction was the absence of threat of irreparable injury in an ordinary criminal proceeding in which an opportunity for defense was provided, with eventual review by the United States Supreme Court should any federal rights be infringed. ${ }^{11}$

Jurisdiction was also declimed in suits to enjoin collection of state or local taxes. The courts often reasoned in terms of an adequate remedy at law in the state courts, which, under Section 16 of the Judiciary Act of $1789,{ }^{12}$ was treated as grounds for denying equitable relief. ${ }^{13}$ That was a mistaken approach, for. Section 16 was later held to refer only to an adequate remedy in the law side of federal courts, and not to state remedies. ${ }^{14}$

628 U.S.C. $\$ \S 2281,2284$ (Supp. 1950). Originally enacted in 1910 to require that interlocutory injunctions against state officials' enforcement of state law be granted only by a special three judge court, one member of which must be from a court of appeals or the Supreme Court. The act was extended in 1913 to apply to imjunctions against state commissions, and in 1925 to apply to permanent injunctions. It applies also to injunctions suspending federal statutes. In an action to enjoin a state statute, it is provided that if any state court has suspended the statute, the federal court must stay its proceedings pending decision in the state court. The act provides for direct appeal to the Supreme Court.

728 U.S.C. $\$ 1341$ (Supp. 1950) (tax) and 28 U.S.C. § 1342 (Supp. 1950) (rates), providing that under certain conditions state taxes and rate orders shall not be suspended or enjomed by federal courts if the states provide an adequate remedy. The current problems discussed in this comment are in areas outside the coverage of these statutes.

8 In re Sawyer, 124 U.S. 200 (1888).

9 Beal v. Missouri Pacific R. Co., 312 U.S. 45 (1941) (violation of full train crew law, held federal court should not intervene); Packard v. Banton, 264 U.S. 140, 143 (1923) (violation of statute requiring motor carriers to insure, Court considered plea because property rights involved, injunction denied on the merits) ; Terrace v. Thompson, 263 U.S. 197, 214 (1923) (statute forbidding aliens who had not made good faith declaration of intent to become citizens to hold land, plea considered because of threat to property rights, but injunction denied on merits).

10 In re Sawyer, supra note 8.

11 Douglas v. Jeannette, 319 U.S. 157, 163 (1943) (selling religious tracts door to door without permit, federal court refused to intervene. Coinpare difficnlty of finding irreparable injury in this case with relative ease in cases cited in note 9 supro. It is suggested that without changing the verbal formula, the Court has drastically increased the area in which jurisdiction will be denied.); Spielman Motor Co. v. Dodge, 295 U.S. 89 (1935) (violation of N.I.R.A. code of fair competition, Court refused to intervene) ; cf. Atlas Ins. Co. v. Southern, Inc., 306 U.S. 563, 569 (1939).

12 Formerly 28 U.S.C. $\$ 384$ (1946), which provided that equitable relief could not be granted if an adequate remedy exists at law. Repealed, 62 STAт. 992 (1948).

18 E.g., Boise Artesian Water Co. v. Boise City, 213 U.S. 276, 281 (1909).

1. Atlas Ins. Co. v. Southern, Inc., supra note 11. 
Absence of threat of irreparable injury is a far better basis for nonintervention of a federal chancellor where adequate state procedure for challenging the tax or its assessinent is provided. ${ }^{15}$ This doctrine was eventually codified in the Tax Injunction Act. ${ }^{16}$

While these two early departures from Marshall's doctrine of coinpulsory jurisdiction were originally based on ancient equitable rules, they soon took their places beside the older rules as independent equitable principles. ${ }^{17}$ They were the first ground swell of the abstemious movement which is now engulfing a major portion of federal equitable jurisdiction.

Beginning in 1929, the list of circumstances under which a federal court would decline to exercise its jurisdiction began to grow rapidly. A movement had begun, and though it was marked by much vacillation and backtracking, the trend was clear. It manifested itself in two nuain lines of decisions: those involving state laws the meaning of which was uncertain, and those involving interference with state administrative agencies. ${ }^{18}$ Both stem from Gilchrist v. Interborough $\mathrm{Co}_{0}{ }^{19}$ Not ouly was this the first case in the new movement towards abstention, but it contained to sonie degree all the problems and all the reasoning which went into the decision of later cases.

In Gilchrist an action was brought by a transportation system to en-

15 Toomer v. Witsell, 334 U.S. 385 (1948); Great Lakes Co. v. Huffman, 319 U.S. 293 (1943) ; Matthews v. Rodgers, 284 U.S. 521 (1932); Dows v. City of Chicago, 11 Wall. 108, 110,112 (1870).

1628 U.S.C. \$ 1341 (Supp. 1950).

17See Meredith v. Winter Haven, 320 U.S. 228, 237 (1943).

${ }_{18} \mathrm{~A}$ few cases do not fit into either category, but seem to depend solely on the pendency of a similar action in a state court. The general rule, stated in Princess Lida v. Thompson, 305 U.S. 456 (1939), is that in an action in rem, the first court to obtain control of the res has exelusive jurisdiction, but in an action in personam, both state and federal courts can proceed until one reaches a judgment that can be set up as res judicata in the other. In Atlas Ins. Co. v. Southern, supra note 11, the Court declared in answer to questions from below that if an action already instituted in state courts provides adequate protection to all the rights of the parties, then no threat of irreparable imjury exists, and the federal chancellor should decline to exercise his jurisdiction. Brillhart v. Excess Ins. Co., 316 U.S. 491 (1942), a declaratory judgment case under the discretionary language of 28 U.S.C. $\$ 400$ (1946), revised in 28 U.S.C. $\$ \S 2201,2202$ (Supp. 1950), held jurisdiction could only be declined after specific findings that all parties were joined in the state action and that all their rights would be adequately protected and all their claims tested. Declaratory judgment proceedings seem to be treated like equitable actions in general. In Chicago v. Fieldcrest Dairies, 316 U.S. 168 (1942), another declaratory judgment case, federal action was stayed though the parties in the state and federal actions were not identical and the federal action was subsequent to the state action. Two recent second circuit cases indicate that courts in that circuit will stay an action in favor of a prior state action for the federal court's convemience, even on the ground that the federal docket is crowded. P. Beiersdorf \& Co. v. McGohey, 187 F.2d 14 (2nd Cir. 1951) ; Mottolese v. KaufInan, 176 F.2d 301 (2nd Cir. 1949), 31 B. U. L. REv. 402 (1951), 25 IND. L. J. 365 (1950), 59 Yate L. J. 978 (1950). The doctrine may not long survive. Judge Frank dissented in the Mottolese case, but wrote the majority opinion in the Beiersdorf case, in which he declared the rule to be wrong, but binding until overruled by the Supreme Court. Judge Clark also dissented, so the majority of the court was opposed to the rule.

19279 U.S. 159 (1929). Some commentators trace these doctrines back to Prentis v. Atlantic Coast Lme, supra note 3. See Young, Discretion to Deny Federal Relief Against State Action, 28 TEx. I. REv. 410, 412, 413 (1950), which contains an excellent general discussion of this subject. 
join a local transit commission from enforcing fares prescribed in the system's franchise. The Supreme Court held that the district court erred in granting the injunction because decision on the merits involved interpretation of extremely doubtful and complicated state laws, the state courts provided an adequate procedure for deciding the state issues, the state procedures had been called into play in an action brought by the transit commission later the same day the federal action was filed, and because the commission was not shown to have acted unreasonably. The decision rested on the combined force of all these facts rather than on any single one.

\section{Noninterference with State Administrative Agencies}

Noninterference with state administrative agencies was first stated as an independent doctrine in Pennsylvania $v$. Williams. ${ }^{20}$ There it was held that a federal court which had taken control of the affairs of an imsolvent state savings institution in a diversity case should have surrendered jurisdiction to a state official charged by law with the liquidation of such institutions. It was said that federal courts, as a matter of discretion, ought not to interfere with the lawful acts of a state officer when the state provides an adequate administrative procedure.

Abdication to administrative agencies was most clearly exemplified in the Railroad Commission of Texas $v$. Rowan \& Nichols Oil Co. ${ }^{21}$ cases involving actions to enjoin operation of state oil proration orders. It was held that, whether a remedy existed in state courts or not, ${ }^{22}$ a federal court should not have granted injunctions which in effect substituted its judgment for that of the state commission in a highly complicated field of regulation, at least in the face of conflicting testimony and uncertainty.

The later case of Burford v. Sun Oil Co. ${ }^{23}$ held that a federal court should leave the reviewing of state agency decisions in such matters to state courts, which, because of familiarity with the problems, would be able to reach a sounder decision. The Court spoke of a state's right to develop its own internal policy, the importance of avoiding friction between state and federal systems, the complexity of the subject, and the skill of state courts.

However, in the same year the Supreme Court held that in a case in which no decision of state law could remove the federal constitutional question, where the state commission had clearly acted in an unconstitutional manner in prescribing gas rates, and where the matter had been in the courts an "inordinately long time," the federal courts should decide the issues of state law and settle the matter. ${ }^{24}$ Thus the matter stood when Meredith v. Winter Haven ${ }^{25}$ was decided in 1943.

20294 U.S. 176 (1935), 13 TEx. L. REv. 479.

21. 311 U.S. 570 (1941); 310 U.S. 573 (1940), as amended, 311 U.S. 614 (1941); Davis, Judicial Emasculation of Administrative Action and Oil Proration: Another View, 19 Tex L. Rev. 29 (1940); Comment, 39 MICH. L. Rev. 438 (1941) ; Note, 51 YaLe L. J. 680 (1942).

22 Railroad Commission of Texas v. Rowan \& Nichols Oil Co., supra note 21 at 311 U.S. 614,615 .

23319 U.S. 315 (1943), 56 HARv. L. Rev. 1162, 42 MICH. L. Rev. 337.

24 Public Utilities Comm'n. v. Gas Co., 317 U.S. 456 (1943).

${ }^{5}$ Supra note 17. 


\section{Interpretation of State Law}

The second major line of cases displaying this abstemious tendency of the federal courts imvolves interpretation of state law. A few years after Gilchrist, the problem arose again in Hawks v. Hamill, in which state officers sought to incorporate a private toll bridge into the state free highway system on the ground that the purportedly perpetual franchise to exact tolls had expired by operation of law. ${ }^{26}$ This time the Court spoke in terms of prudent self-restraint, and said that when jurisdiction rests solely on diversity of citizenship, and when the applicable law is uncertain, federal courts slould be particularly reluctant to interfere with local officials in a matter of local interest.

In Hawks v. Hamill and similar cases, the Court has been much troubled by the presence of undecided issues of state law. It recognizes that in a subsequent case a state court may apply a different interpretation to state law than that adopted by the federal courts. ${ }^{27}$ The federal courts would then suffer the double embarrassment of having misconstrued the law and having denied justice to a litigant.

Various devices liave been tried in order to protect litigants' interests. In Hawks v. Hamill the action was dismissed. In two 1934 cases the Court experimented with a tentative decision on state issues, granting the parties leave to apply by bill or otherwise at any time for appropriate relief should the state courts develop an inconsistent construction of the statutes involved. ${ }^{28}$

In 1940 still another device was tried. It was held that a federal bankruptcy court, while retaining general control of the affairs of the debtor, could allow the trustee to subimit a doubtful question of state law regarding the nature of the debtor's interest in land to a state court for decision. ${ }^{29}$ The use of a soinewhat similar procedure involving obtaining state declaratory judgments on issues of state law in federal cases was suggested recently in a concurring opinion by $\mathrm{Mr}$. Justice Frankfurter. ${ }^{30}$ This is a revolutionary procedure, and if widely applied would radically change the nature and function of our federal courts, creating a federal-state relationship comparable in some ways to that existing between a chancellor and a master.

The possibility of avoiding federal constitutional questions by preliminary decision on state issues was emphasized in Railroad Commission $v$. Pullman Co., ${ }^{31}$ which involved the constitutionality of a Texas commission's administrative order regulating the assignment of Pullman porters

26288 U.S. 52, 61 (1933).

27 This consideration became even more important after the decision of Erie R. R. Co. v. Tompkins, 304 U.S. 64 (1938), which required the federal courts to apply local case law as well as statute law. The influence of Erie v. Tompkins on the problem of abstention is bricfly discussed in Note, 25 IND. L. J. 316 (1950).

28 Lee v. Bickell, 292 U.S. 415 (1934); Glenn v. Field Packing Co., 290 U.S. 177 (1933).

29 Thompson v. Magnohia Co., 309 U.S. 478 (1940), 53 HARv. L. REV. 1394, 7 U. OF Cm. L. REv. 727, 3 U. OF DETROIT L. J. 212.

30 Sutton v. Leib, 342 U.S. 402,412 (1952). The case deals with a conflict of law problem relative to marital status and alimony.

31312 U.S. 496 (1941), 54 Harv. L. Rev. 1379, 50 Yale L. J. 1272, 41 Cor. I. Rev. 925. 
and conductors. The action was ordered stayed until the meaning and application of the order could be determined in state courts. This procedure served the double function of avoiding a constitutional question, since not all the various possible interpretations of the order would be unconstitutional, and also of avoiding a possibly erroneous statement of state law, the Court not wishing to make a tentative forecast that might later be displaced by a state court decision. The Court particularly sought to avoid resting a constitutional decision on an erroneous construction of the order.

Several early opinions indicated the Court was less reluctant to abstain from judgment in diversity cases than federal question cases, but later cases have shown exactly the opposite view. In Hawks v. Hamill the Court declared it was particularly willing to decline to exercise jurisdiction which rests solely on diversity of citizenship. ${ }^{32}$ Chicago $v$. Fieldcrest Dairies represented the extreme extension of that viewpoint. ${ }^{33}$ It was a diversity action ${ }^{34}$ by a corporation for a declaratory judgment to challenge the actions of local officials requiring use of glass milk bottles under an ordinance calling for standard containers. It was held that the action sliould have been stayed pending construction of the ordinance in a state action, to which Fieldcrest was not a party, brought by its parent company subsequent to the federal action.

\section{Meredith v. Winter Haven Applies the Brakes}

Only a year after the Fieldcrest case the Court abruptly reversed its field. In Meredith v. Winter Haven it declared that in diversity cases federal courts are bound to decide the state issues, however confused and doubtful, unless exceptional circumstances exist. ${ }^{35}$ To refuse to do so would in effect emasculate diversity jurisdiction. Meredith was an action for a declaratory judgment and for an injunction preventing the City of Winter Haven from retiring mumicipal bonds without providing for payment of deferred interest coupons. No constitutional issues were involved and no state statutes were challenged. Because of conflict in state court decisions, the lower federal courts had declared themselves unable to determine the state law with certainty.

After deciding that on the facts before it, the district court was under a duty to reach a decision on the merits, the Supreme Court went on to declare that under certain exceptional circumstances a federal court could decline to exercise its jurisdiction, even in a diversity case. These special conditions involve:

1. interference with a recognized, defined public policy,

2. interference with state criminal prosecutions,

3. interference with state tax collections and fiscal policy,

\footnotetext{
32 Supra note 26.

33 Supra note 18.

34 Id. at I73. The court said a constitutional question was lurking in the case, but regarded it as "unsubstantial." Apparently this did not influence the decision.

35 Supra note 17. See Notes, 48 Cor. L. Rev. 575 (1948), 53 Yale L. J. 788 (1944).
} 
4. interference with, appraisal of, or shaping of state policies regarding administrative agencies,

5. interference with state administration of state financial institutions,

6. failure of the plaintiff to prove an equitable cause of action,

7. deciding a constitutional question if a decision on state law might make it unnecessary-a matter of discretion if no state action is pending, but a matter of duty if a state action is pending which might have that effect. . $^{36}$

This list appears to be only a partial judicial codification of pre-existing case law. Such cases as Thompson v. Magnolia, ${ }^{3 T}$ Hawess v. Hamill, ${ }^{38}$ and Chicago v. Fieldcrest Dairies ${ }^{39}$ are very difficult to reconcile with Meredith, but those cases do not seem to be dead. They are still cited as authorities in federal courts, even in the Supreme Court.

The reason for the drastic reversal in the Meredith case is not clear. Apparently the Court suddenly decided to stop the movement towards abstention in ordinary diversity cases, but did not wish to overrule its earlier decisions in areas in which abstention had become firmly imbedded. The Court may have recalled that the oft stated purpose of diversity jurisdiction was to place interstate cases in strong creditor's courts rather than in state courts which might be too friendly to debtors or which might discriminate against the "foreigner", ${ }^{40}$ or it may have been influenced by the fact it was dealing with a mere municipality rather than a state. More likely it had finally realized that if diversity jurisdiction is to exist at all, diversity cases must be decided by the district courts. Federal question cases can be reviewed by the.Supreme Court after decision of questions of fact and state law in state courts, but if diversity cases do not start in federal courts, no federal hearing can ever be granted. The Meredith decision may have been intended to leave to Congress the final decision as to the desirability of diversity jurisdiction.

Noninterference with State Administrative Agencies Since Meredith v. Winter Haven

Dicta in Meredith $v$. Winter Haven listed the avoidance of interference with state admimistrative agencies as a proper ground for declining jurisdiction. The Court apparently did not wish to change the pre-existing law on that subject. As Chief Justice Vimson recently restated it in Alabama Public Service Comm'n. v. Southern R. Co.:

In Meredith $v$. Winter Haven, ... the Court sustained the exercise of jurisdiction by a federal court in a case involving matters of state law, but only where decision "does not require the federal court to determine or shape state policy governing administrative agencies" and "entails no interference with such agencies or with state courts." The absence of a legal remedy

\footnotetext{
36 Supra note 17 at 237.

37 Supra note 29.

38 Supra note 26.

39 Supra note 18.

${ }^{40}$ Friendly, The Historic Basis of Diversity Jurisdiction, 41 HARv. L. REv. 483, 498 (1928).
} 
in the federal courts does not of itself justify the granting of equitable relief in such cases . . . . 41

Alabama, the latest in this line of cases, appears to extend the doctrine of abstention further than ever before. ${ }^{42}$ On grounds of public convenience and necessity, the state commission refused permission for the railroad to abandon unprofitable intrastate service. The railroad brought an action in federal court on grounds both of diversity and due process to enjoin the commission from enforcmg a state law prohibiting abandonment of service without permission from the commission. No problem of interpretation of state statutes was involved, nor was the constitutionality of the statute itself involved. The sole question was the propriety of the commission's action. It was held to be error for the district court to grant an injunction. It should, as a matter of discretion, have declined to exercise its jurisdiction, since the issue was of purely local concern. The federal chancellor should have scrupulous regard for the independence of the states and must seek to avoid needless friction with state authorities. Thus reasoned the Court. The case could have been decided on the basis of avoidance of a constitutional question, but it was not. It was decided on grounds of comity, and despite the admitted fact that the state review procedure is much more awkward and provides far less protection than does federal procedure.

This case appears to impose a rule of exhaustion of judicial remedies analogous to the Prentis rule of exhaustion of administrative remedies. ${ }^{43}$ It seems to absolutely foreclose the granting of injunctions by federal courts against the actions of state administrative agencies, at least if the state provides a review procedure, even a relatively inadequate one. The Supreme Court can still rule on federal questions, since the cases can come before it by appeal or certiorari from the highest state courts. This procedure has the advantage of deciding state issues at home, and also of saving the time and energy of federal courts for strictly federal business.

Justice Frankfurter, joined by Justice Jackson, wrote a concurring opinion to the Alabama Public Service case declaring that this decision is in "flagrant contradiction with the unbroken course of decisions in this Court for seventy-five years." furter appears to be unaware of some of the most momentous decisions of the last twenty-five years.

\section{Interpretation of State Law Since Meredith v. Winter Haven}

The present status of Meredith $v$. Winter Haven as a precedent in cases involving interpretation of state law is not clear. Some cases have been

41341 U.S. 341,351 (1951).

42 Ibid. See Comments, 19 U. of CFr. L. Rev. 361 (1952), 31 B. U. L. Rev. 533, 51 CoL. L. Rev. 899 (1951), 37 VA. L. Rev. 1007 (1951).

43 Supra note 3.

44 Supra note 41 at 362 . Comment, 46 IIL. L. REv. 756 (1951) supports Justice Frankfurter. For an interesting contrast, see Justice Frankfurter's concurring opinion in Sutton v. Leib, supra note 30 at 412 , which begins, "This case illustrates what little excuse is left for diversity jurisdiction, certainly since Erie R. Co. v. Tompkins, . . " and goes on to suggest the use of state declaratory judgment procedures to settle state law preliminary to federal decision, 
decided on its authority, following either its holding ${ }^{45}$ or its dicta. ${ }^{46}$ Other cases that could have been decided on its authority either have ignored it completely ${ }^{47}$ or have cited it incidentally, ${ }^{48}$ but have relied on older decisions. The latter cases contain language which cannot be reconciled with Meredith.

In a decision following the strict rule of the Meredith case, it was held that a federal court acted properly in declaring that the Alien Property Custodian succeeded to the interests of heirs whose rights were being adjudicated in a state court, although the decision required settlement of doubtful questions of state law concerning the exact moment at which the heirs took an interest in the property, and also involved an incursion into the state court's probate jurisdiction. ${ }^{40}$ Other cases have held that federal courts have a duty to decide dubious points of state law, and that the decision of the lower courts will be final unless clearly wrong. ${ }^{60}$ Those cases involve the application nil equitable actions of the rules commonly applied in legal suits. ${ }^{5 \overline{1}}$

A different approach is shown in $A . F$. of $L . v$. Watson, ${ }^{52}$ in which an injunction was sought against the enforcement of a state constitutional provision which had never been construed, and which was alleged to involve a denial of due process, and also to be contrary to federal labor laws and therefore invalid under the supremacy clause. It was held to be error for the district court to try the case on its nerits. The action should have been stayed pending an authoritative interpretation by state courts. The case could have been decided on the basis of the exceptions listed in Meredith $v$. Winter Haven. Instead, it was decided on the authority of older cases, and Meredith was not cited in the entire course of the opinion. Apparently the wisdom of Meredith no longer strongly appealed to the Court.

The principle of abstention was applied in Stainback v. Mo Hock Ke Lok $P o$ to an action to enjoin the operation of a Territory of Hawaii act regulating foreign language instruction. ${ }^{33}$ While a constitutional issue existed, it was not relied upon as a ground for decision, and Meredith was

45 Spiegel v. Comm'r., 335 U.S. 701, 707, 708 (1949); Propper v. Clark, 337 U.S. 472 (1949); Markham v. Allen, 326 U.S. 490, 495, 496 (1946).

46 Spector Motor Co. v. McLaughlin, 323 U.S. 101 (1944), 20 Notre DaMe LAw. 170, a diversity case to enjoin a state tax, $\mathrm{m}$ federal court despite the TAx INJUNCrion AcT, supra note 7 , because of doubt as to state remedies, was stayed pending state construction of the statute in order to avoid a constitutional question.

47 A. F. of L. v. Watson, 327 U.S. 582 (1946), 22 IND. L. J. 87, 20 So. CaIm. L. Rev. 217 (1947).

48 Stainback v. Mo Hock Ke Lok Po, 336 U.S. 368 (1949). Some court of appeals cases seem to he contrary to Meredith also. Mottolese v. Kaufman, supra note 18 , suggests that a federal court can decline jurisdiction for its own convenience, and was so construed in P. Beiers'dorf \& Co. v. McGohey, supra note 18 (federal question case).

40 Markham v. Allen, supra note 45.

50 Spiegel v. Comm'r., supra note 45 (question of existence of possibility of reverter);

Propper v. Clark, supra note 45 (interest of Alien Property Custodian).

51 E.g., Palmer v. Hoffman, 318 U. S. 109 (1943); cf. Sutton v. Leib, supra note 30.

52 Supra note 47.

53 Supra note 48 . 
only casually mentioned. The Court remarked that federal rights could be adequately protected in territorial courts, with review by the Supreme Court, and spoke at length of comity and due regard for the independence of local governmental bodies. The flavor of the opinion was very much like that of the subsequent Alabama Public Service Commission case. ${ }^{54}$ Justice Reed, delivering the opinion of the court, stated that:

... territorial like state courts are the natural sources for the interpretation and application of the acts of their legislatures and equally of the propriety of interference by injunction. We think that where equitable interference with state and territorial acts is sought in federal courts, judicial consideration of acts of importance primarily to the people of the state or territory should, as a matter of discretion, be left by the federal courts to the courts of the legislating authority unless exceptional circumstances command a different course. .5

This statement, if it is to be credited, appears clearly to establish that local statutes will not be enjoined by federal courts until state courts have construed them, at least in the absence of "exceptional circumstances." Those words in the Stainback opinion may have been simply a method of hedging, or they might have been intended to express the existence of real limits to the holding. We are not told.

The following year the rule of abstention was applied as a matter of course in an action for an injunction against an allegedly unconstitutional state statute. In a per curiam decision, ${ }^{56}$ citing only the $A$.F. of $L$. case, it was held that the district court erred in trying the matter on its merits. It should have stayed the action pending state interpretation of the statute.

A litigant seeking to avoid a contest in federal court would be wise to try to bring his cause within the exceptions listed in the Meredith opinion, but he need not abandon hope should he be unable to do so. Meredith is not the last word, and it may not be the word at all inuch longer.

\section{Conclusion}

The Stainback doctrine and the Alabama Public Service ${ }^{57}$ case together seem to almost, if not completely, wipe out the jurisdiction gained by federal courts in Ex Parte Young, ${ }^{58}$ at least as long as the states provide their own review procedures. Thus a complete revolution appears to have taken place within half a century. It may well be that the three judge courts ${ }^{59}$ will be left without any function regarding state law and administrative agencies. On the other hand, the Supreme Court may again attempt to reverse the tide, as it did in Meredith $v$. Winter Haven.

Most of the cases holding for abstention are decided on the basis of what is called "discretion." It is important to realize that there is "discre-

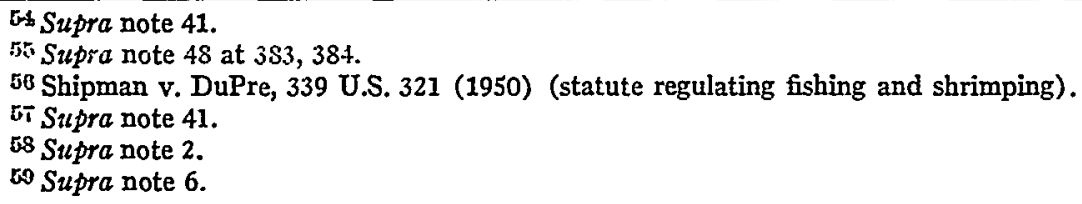


tion" only to decline jurisdiction, not to exercise it. This is a backhand way of saying no jurisdiction exists without flying in the teeth of the statutes and without opening decisions to collateral attack.

From the viewpoint of the Court, it would seem to be very desirable to channel as many cases as possible involving state agencies or doubtful points of state law through state courts. First, a decision of the state question will often obviate a federal constitutional decision. Second, by this method the federal courts can avoid the embarrassment of searching through lower state court decisions in order to make a tentative forecast of what the highest state court will decide about the law. Rights of litigants will be protected from the possibility of suffering an adverse federal decision on what may later turn out to be an erroneous construction of state law. Further, a great saving of time and energy is possible, since cases are delivered to the Supreme Court by state courts in a neat package, with all questions of state law and most questions of fact neatly tied up with ribbon. Many cases will never reach the federal level, but will be finally settled in state courts, especially if the doctrine of abstention is applied freely to diversity cases. The time saved would prove valuable in handling the ever increasing burden of purely federal cases. Finally, the factors of comity and local interest appear to be of great importance to the Court. The disadvantages arising from the use of older, generally slower and more awkward state procedures, the possibility of discrimination against the "alien" in diversity cases, and the imposition of an additional level of appellate review do not seem sufficiently weighty to balance the scales against abstention. It seems to be a desirable movement, and it is probable that it will spread to new areas in the future, possibly even to diversity cases at law through an extension of something hike forum non conveniens.

The principal difficulty now is the uncertainty as to whether or not the Supreme Court will decide the district court should have declined to exercise its jurisdiction. Litigants entering federal courts frequently run the risk of fighting a case all the way to the Supreme Court only to be told to go back and start over in a state court. It would be desirable for the Court to spell out more definite rules for the guidance of both litigants and lower federal courts. However, it is probable that the only permanent remedy for the present confusion lies in the hands of Congress.

Thomas C. Ackerman, Jr. 